\title{
Bioaccumulation of heavy metals by Vibrio alginolyticus isolated from wastes of Iron and Steal Factory, Helwan, Egypt
}

\author{
Hoda H. El-Hendawy ${ }^{1}$, Dena A. Ali ${ }^{2}$, Enas H. El-Shatoury ${ }^{2}$ and \\ Samah M.Ghanem ${ }^{1}$ \\ 1- Botany Department, Helwan University \\ 2- Microbiology Department, Ain Shams University
}

\begin{abstract}
The isolation of bacteria resistant to heavy metals is a topic of interest in the field bioremediation of contaminated water, soil and sediments. We report here the isolation of bacteria that is resistant to high concentration of a mixture of heavy metals namely cadmium, cupper, lead and zinc. The bacterial isolate was obtained from a site receiving heavy metal waste from the iron and steal factory; a major factory located in El-tebeen, south Helwan. The isolate was identified as Vibrio alginolyticus using the API system. The maximum tolerable concentration was 2.5 $\mathrm{mM}, 4 \mathrm{mM}, 2.5 \mathrm{mM}$ and $3.5 \mathrm{mM}$ for cadmium, copper, lead and zinc respectively. Transmission electron micrograph of Vibrio alginolyticus grown in nutrient broth containing a mixture of the four tested heavy metals, showed bioaccumulation of heavy metal(s) on the bacterial cell wall. At the same time, there was an over all reduction in the concentration of heavy metals in culture supernatant; the percentage reduction was $20 \%$ for cadmium, $31 \%$ for cupper $40 \%$ for lead and $45 \%$ for zinc. The reduction occurred after $4 \mathrm{hrs}$ incubation at $30^{\circ} \mathrm{C}$ for all metals, cupper, lead, and zinc while cadmium required $24 \mathrm{hrs}$ incubation were required to achieve maximum reduction. This isolate could be used to accelerate the in situ bioremediation of sites contaminated by loads of mixed metals.
\end{abstract}

Keywords:

\section{INTRODUCTION}

Industrial activities led to substantial release of toxic metals into the environment. Heavy metals constitute a major hazard for the human health and ecosystem (Boopathy, 2000).

The Iron and Steal Factory was constructed in 1947 and is major factory with estimated sales 1.8 million pounds / year.

According to Kaiser (1980), heavy metals are defined as ions with partially or completely filled $d$-orbital. Some metals including iron, zinc, copper and manganese are micronutrients used in the redox processes, regulation of osmotic pressure, enzymes cofactors and are also important in the maintenance of the protein structure (Vallee and Auld 1990). However even essential metals such as zinc and copper are toxic at high concentration.

On the other hand metals including lead and cadmium do not play any known physiological role and are in fact toxic to cells. Lead reacts with the sulphydryl groups of protein and inhibits their function; cadmium is extremely toxic and was shown to induce DNA breakage (Ron et al., 1992). The metal ion toxicity is determined by many factors such as physio-chemicals characters of metals ion including electro- negativity, reduction-oxidation potential,......etc. (Workentine et al., 2008).

Chemical methods such as precipitation, oxidation or reduction 
have been widely used to remove metal ions from industrial waste water. Those methods are ineffective or expensive (Volesky, 1990). The activity of microorganisms is extended to environmental management, and microbes have superseded the conventional techniques of remediation Vidali (2001). Biological methods such as biosorption and bioaccumulation provide promising alternative to chemical methods (Kapoor and Viraragharan, 1995).

The mechanism by which microorganisms remove heavy metals can be divided into three categories; the first mechanism is the biosorption of metals ions on the cell surface, second intracellular uptake of metals ion and third chemical transformation of metal ions by microorganism (Pardo et al., 2003). Among the different technique employed for metals removal from multi elemental system, biosorption has been found to be highly selective (Knauer et al., 1997). Furthermore metal accumulating bacteria can be used to remove, concentrate and recover metals from industrial effluents (Malekzadeh et al., 2002 and Chowdhury et al., 2008).

The capacity of any biosorbent is mainly influenced by biomass characteristic, physiochemical properties of the target metals, and the micro environment of contact solution including $\mathrm{pH}$, temperature and interaction with other ions (Chen and Wang 2007). Moreover once the toxic metals are adsorbed or transferred within organic materials they can be removed from waste water (Smith and Collins, 2007).

The aim of this study was to isolates and characterizes bacteria from sites receiving heavy metals pollutants, to study the heavy metals resistance pattern and the bioaccumulation potential of the selected organism.

\section{MATERIALS AND METHODS Sample collection and total bacteria count}

Water samples receiving waste from the Iron and Steal Factory, ElTebeen, Helwan, Egypt were collected, and three replicates were considered. The initial $\mathrm{pH}$ was determined at the site of collection Samples were kept in ice and sent to lab for heavy metal analysis. For total count samples were stored at $4^{\circ} \mathrm{C}$. Then $0.1 \mathrm{ml}$ of the water sample was inoculated into nutrient agar plates. Plates were incubated at $30^{\circ} \mathrm{C}$ for $24 \mathrm{hrs}$.

\section{Heavy metals analysis}

The heavy metal content of the water sample was determined according to Cunningham and Lundie (1993); where 1 $\mathrm{ml}$ nitric acid was added, after over night incubation the result liquid was diluted, the concentrations of $\mathrm{Cd}^{+2}, \mathrm{Cu}^{+2} \mathrm{~Pb}^{+2}, \mathrm{Zn}^{+2}$ and $\mathrm{Fe}^{+3}$ were determined using the atomic adsorption spectrophotometer 3100 Perkin- El-MER, Central Laboratory Ain Shams University.

\section{Dertermination of MTCs (maximum tolerable concentration)}

To test the heavy metals resistance pattern, the heavy metals $\mathrm{Cd}^{+2}, \mathrm{Cu}^{+2}, \mathrm{~Pb}^{+2}$ and $\mathrm{Zn}^{+2}$ used as $\left(\mathrm{CdNO}_{3}\right)_{2} .4 \mathrm{H}_{2} \mathrm{O}, \mathrm{CuSO}_{4} .7 \mathrm{H}_{2} \mathrm{O}, \mathrm{C}_{4} \mathrm{H}_{6} \mathrm{O}_{4} \mathrm{~Pb}$.

$3 \mathrm{H}_{2} \mathrm{O}$ and $\mathrm{Zn} \mathrm{SO}_{4} \cdot 7 \mathrm{H}_{2} \mathrm{O}$ were added to nutrient agar media at concentrations covering the range from $0.1 \mathrm{mM}$ to 4.0 $\mathrm{mM}$, plates were then spot inoculated and incubated at $30^{\circ} \mathrm{C}$ for $24 \mathrm{hrs}$. The maximum tolerable concentration (MTC) of heavy metals was designated as the highest concentration of heavy metals that allowed growth after $24 \mathrm{hrs}$ (Schmiatt and Schlegel, 1994). The most tolerable isolate was selected.

\section{Bacterial characterization}

The most tolerable bacterial isolate was characterized using analytical profile index (API system) biochemical test kit KB002 Hi Assorted Hi media, India.

\section{Metals reduction measurements:}

Bacteria were grown on $100 \mathrm{ml}$ nutrient broth for 24 hours. Cells were harvested by centrifugation and suspended 
in $1 \mathrm{ml} 0.08 \%$ saline solution. Cell pellets were transferred into nutrient broth media containing a mixture of heavy metals. The

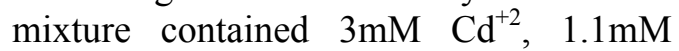
$\mathrm{Cu}^{+2}, 1 \mathrm{mM} \mathrm{Pb}$ and $1.1 \mathrm{mM} \quad \mathrm{Zn}^{+2}$ (Mergeay et al., 1985). At time intervals the metal content was determined in the cell free supernatant using atomic adsorption spectroscopy (Gainji and Page 1974).

\section{Electron microscopy}

Electron microscopy was performed through the electron microscope facility, at Ain Shams University. Pellet of $24 \mathrm{hrs}$ cultures grown on media with and without heavy metals were examined. Briefly cells were fixed in $2.5 \%(\mathrm{v} / \mathrm{v})$ glutaraldhyde, the sample was post fixed in osmium tetraoxide then dehydrated in ethanol. Thin sections were prepared and examined using Jeol-JEM 1200 EX II transmission electron microscope. Japan (Crooks et al., 1986).

\section{RESULTS}

The initial $\mathrm{pH}$ of sample was 1.9. The heavy metals content of the water sample from which the bacteria was isolated was estimated as: 0.05 $\mathrm{mg} / \mathrm{l}$ cadmium, $0.024 \mathrm{mg} / \mathrm{l}$ copper, $0.32 \mathrm{mg} / \mathrm{l} \mathrm{lead}, 18.1 \mathrm{mg} / \mathrm{l}$ zinc and 1.13 $\mathrm{mg} / \mathrm{l}$ iron.

The colony forming units was found to be $125 \times 10$. Based on colonial morphology, nine distinct colonies were, isolated, purified, and recognized. The isolate that tolerated high concentration of heavy metal $\left(2.5 \mathrm{mM} \mathrm{Cd} \mathrm{Cd}^{+2}, 4 \mathrm{mM} \mathrm{Cu} \mathrm{Cu}^{+2}, 2.5 \mathrm{mM}\right.$ $\mathrm{Pb}^{+2}$ and $3.5 \mathrm{mM} \mathrm{Zn}^{+2}$ ) was selected for identification and used for further studies.

Accordingly to the cell morphology, Gram reaction and biochemical characterization tests (Table1) the selected isolate was identified as Vibrio alginolyticus.

In nutrient broth containing a mixture of heavy metals, $V$. alginolyticus was able to reduce the concentration of all tested metals the percentage reduction was $20 \%$ for cadmium, $31 \%$ for copper, $40 \%$ for lead and $45 \%$ for zinc. Maximum reduction was achieved at $30^{\circ} \mathrm{C}$ after $4 \mathrm{hrs}$ incubation for all heavy metals except cadmium were $24 \mathrm{hrs}$ incubation were required to attain maximum reduction .

Table 1: Biochemical characterization tests of the selected isolate.

\begin{tabular}{|c|c|}
\hline Test & Result \\
\hline Citrate utilization & -ve \\
Lysine decarboxylation & $+\mathrm{ve}$ \\
Ornithine decarboxylation & variable \\
Urease & $-\mathrm{ve}$ \\
Phenyl alanine deamination & -ve \\
$\mathrm{Nitrate}^{\mathrm{S}}$ reduction & $+\mathrm{ve}$ \\
$\mathrm{H}_{2} \mathrm{~S}$ production & $-\mathrm{ve}$ \\
Glucose & $+\mathrm{ve}$ \\
Adonitol & $-\mathrm{ve}$ \\
Lactose & $-\mathrm{ve}$ \\
Arabinose & $-\mathrm{ve}$ \\
Sorbitol & $-\mathrm{ve}$ \\
\hline
\end{tabular}

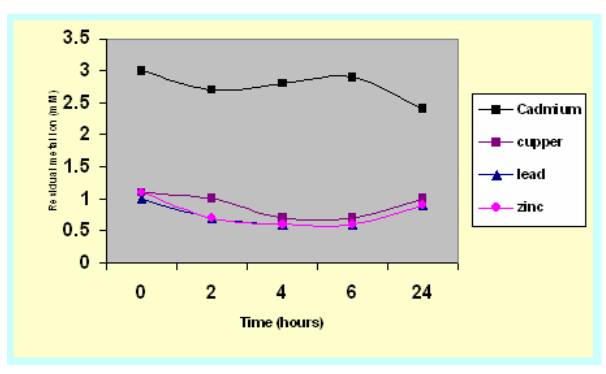

Fig.1: Metal reduction as a function of time

As shown in (Fig. 2) $V$. alginolyticus was grown on nutrient broth containing a mixture of heavy metal, electron microscopic analysis revealed localized areas of heavy metals at the cell surface indicating possible accumulation by binding to the cell wall.

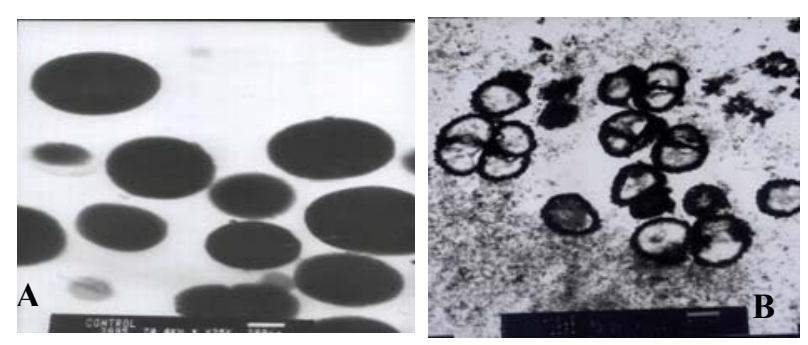

Fig. 2: Transmission electron micrographs of $V$. alginolyticus grown for $24 \mathrm{hrs}$ at $30^{\circ} \mathrm{C}$. (A) Cells grown on nutrient broth.(B) Cell grown on nutrient broth containing a mixture of heavy metals. Cells showing localized precipitation of heavy metal(s) on the cell surface. Bar $1 \mu \mathrm{m}$. 


\section{DISCUSSION}

According to the standards permitted by the Ministry of Environmental Affairs in Egypt, the water sample obtained from wastes of Iron and Steal Factory contained above the permitted amounts of cadmium, lead and zinc. There was 10 times more $\mathrm{Cd}^{+2}, 16$ times more $\mathrm{Pb}^{+2}$ and 3 times more $\mathrm{Zn}^{+2}$ in the water sample, leakage of the waste water would cause heavy metal contamination of the ground water. Among the four tested heavy metals cadmium is considered the most toxic metal. Cadmium is more mobile than other heavy metals because of the low affinity between soil particles to cadmium (Cunninngham and Lundi, 1993).

Resistance of toxic metals in bacteria probably reflects the degree of environmental contamination with these metals (Aiking et al., 1984 and Malik and Jaiswal 2000).

According to Malik and Jaiswal, 2000 there is no acceptable concentration of metal ions which can be used to distinguish metal resistant and metal sensitive bacteria.

The presence of metal resistant microbes was reported by many authors. Hetzer et al. 2006 isolated members of the Genus Geobacillus that were all considered resistant to cadmium at concentrations ranging between $0.4 \mathrm{mM}$ to $3.2 \mathrm{mM}$. In this study $V$. alginolyticus was resistant to $2.5 \mathrm{mM} \mathrm{Cd}^{+2}$. Moreover Dressler et al., 1991 reported that Alcaligenes denitrificans tolerated copper up to 4 $\mathrm{mM}$, in this study $V$. alginolyticus was resistant to $4 \mathrm{mM} \mathrm{Cu}^{+2}$.

Richard et al., 2002 reported that $\mathrm{Cu}^{+2}$ and $\mathrm{Pb}^{+2}$ appear to bind to materials on the cell surface. Lead is precipitated in an insoluble form that is localized to the cell membrane or cell surface (Aiking et al., 1985; Levinson et al., 1996; Roane 1999) similar results were obtained from this study showing localization of one or more metal to cell wall of $V$. alginolyticus. This could be generally explained by the fact that the negatively charged groups (carboxyl, hydroxyl and phosophryl) of bacterial cell wall absorb metal cations through various mechanisms such as electrostatic interaction, van der Waals forces, covalent bonding or combination of such processes (Chojnacka et al., 2005).Both dead and living cells adsorb metal ions (Ansari and Malik 2007).

Pardo, et al., 2003 reported that the percentage removal of $\mathrm{Cd}^{+2}, \mathrm{Cu}^{+2}$, $\mathrm{Pb}^{+2}$ and $\mathrm{Zn}^{+2}$ from aqueous solution by Pseudomonas putida was $80 \%$, in this study the percentage reduction by $V$. alginolyticus was $20 \% \mathrm{Cd}, 31 \%$ $\mathrm{Cu}^{+2}, 40 \% \mathrm{~Pb}^{+2}$ and $45 \% \mathrm{Zn}^{+2}$. Further investigation are needed to increase the rate of bioaccumulation by $V$. alginolyticus .Due to the metal uptaking ability of $V$. alginolyticus it could be used either as pure culture, in mixed consortium to treat industrial effluents before release to the environment or it could be genetically manipulated to increase the rate and efficiency of metal removal capability.

\section{REFERENCE}

Aiking, H.; Govers, H. and van't Riet, J. (1985). Detoxification of mercury, cadmium, and lead in Klebsiella aerogenes NCTC 418 growing in continuous culture. Appl. Environ. Microbiol. 50:1262-1267.

Ansari, M. I. and Malik, A. (2007). Biosorption of nickel and cadmium by metal resistant bacterial isolates from agricultural soil irrigated with industrial waste water $>$ bioresource Technology 98 (16): 3149-3153.

Boopathy, R. (2000). Factors limiting bioremediation technologies. Bioresource Technology 74: 63-67.

Chen, C. and Wang, J. (2007). Correlation metal ionic characteristics with biosorption capacity using QSAR model. Chemosphere. 69:1610-1616.

Chojnacka, K.; Chojnacki, A. and Gorecka, H. (2005). Biosorption of $\mathrm{Cr}^{+2}, \mathrm{Cd}^{+2}$ and $\mathrm{Cu}^{+2}$ ions by blue green alga Spirulina 
sp. Kinetics, equilibrium and the mechanism of the processes. Chemosphere 59:75-84.

Chowdhury, S.; Mishra, M.; Adarsh, V. K.; Mukherje, A.; Thakur, A. R. and Chadhuri, S. R. (2008). Novel metal accumulator and protease secretor microbes from east Calcutta wetland. American Journal of biochemistry and biotechnology 4(3): 255-264.

Crooks, S.M.; Treml, S.B. and Collins, M.L.P. (1986). Immunocytochemical ultrastuctural analysis of chromatophore membrane formation in Rhodospirillum rubrum. Journal bacteriol.167:89-95.

Cunningham, D.P. and Lundie, L. L. Jr. (1993). Precipitation of cadmium by Clostridium thermoaceticum. Appl Environ Microbiol. 59(1):7-14.

Dressler, C.; Kues, U.; Nies, D.H. and Friedrich, B. (1991). Determinants encoding multiple metal resistance in newly isolated copper-resistant bacteria. Applied.Environ. Microbiology. 57:3079-3085.

Ganji, T.J. and Page, A.L. (1974). Rapid acid dissolution of plant tissue for cadmium determination by atomic absorption spectrophotometer .Atomic Absorption Newsl. 13:131-134.

Hetzer, A.; Christopher, J.D. and Hugh, W.M. (2006). Cadmium ion biosorpation by the thermophilic bacteria Geobacillus stearothermophilus and $G$. thermocatenulatus. Appl and Env Microbiology. 72:4020-4027.

Kaiser, K.L. (1980). Correlation and prediction of metal toxicity to aquatic biota, Canadian journal of fish and Aquatic science 37:211-218.

Kapoor, A. and Viraragharan, T. (1995). Fungal biosorption - an alternative treatment option for heavy metals bearing waste water. Bioresource technology, 53:195-206.

Knauer, M.F.; Kridel, S.J.; Hawley, S.B. and Knauer, D.J. (1997). The efficient catabolism of thrombin-protease nexin 1 complex is a synergistic mechanism that requires both the LDL receptor-related protein and cell surface heparins. $J$. Biol. Chem. 272:29039-29045.

Levinson, H.S.; Mahler, I.; Blackwelder, P. and Hood, T. (1996). Lead resistance and sensitivity in Staphylococcus aureus. Microbial. Lett. 145:421-425.

Malekzadeh, F.; Farazmand, A.; Ghafourian, H.; Shahamat, M.; Levin, M. and Colwell, R. R. (2002). Uranium bioaccumulation by a bacterium isolated from electroplating effluent. World J. Microbiol. Biotechnol 18(4): 295-302.

Malik, A. and Jaiswal, R. (2000). Metal resistance in Pseudomonas strains isolated from soil treated with industrial wastewater. World J. of Microbioloogy and Biotechnology. 16: 177-182.

Mergeay, M.; Nies, D.; Schlegel, H.G.; Gerits, J.; Charles, P. and Gusegen, F. (1985). Alcaligenes eutrophus $\mathrm{CH} 34$ is a facultative chemolithotroph with plasmid-bound resistance to heavy metals. J. Bacteriol. 162: 328-334.

Pardo, R.; Herguedas, M. and Barrado, E. (2003). Biosorption of cadmium , copper, lead and zinc by inactive biomass of Pseudomonas putida. Analytical and Bioanalytical chemistry. 376:26-32.

Richard, W.; Glenn, D. Krumholz; Matthew, S. Chval and Louis, S. Tisa (2002). Heavy metal resistance pattern of frankia strains. applied and environ. Microbiology. 68:923-927.

Roane, T.M (1999). Lead resistance in two bacterial isolates from heavy metalcontaminated soils. Microb .Ecol. 37:218-224

Ron, E.Z.; Minz, D.; Finkelstein, N. and Rosecnberg, E. (1992). Introduction of bacteria with cadmium. Biodegradation 3: 161-171.

Schmiatt, T. and Schlege, H.G. (1994). Combined Nickel - Cobalt - Cadmium resistance encoded by ncc Locus of Alcaligenes xylosoxidans 31A.J. Bacteriology 176(22): 7045-7054.

Smith, J.L. and Colllins, H.P. (2007). Management of organisms and their processes in soils,. In Soil Microbiology, ecology and biochem., ed by Eldor A.P.. Elsevier Inc., Bulington, USA pp.389-430.

Vallee, B.L. and Auld, D.S. (1990). Zinc coordination, function, and structure of zinc enzymes and other proteins. Biochemistry 29: 5647-5659.

Vidali, M. (2001). Bioremediation. An overview. Pure Applied Chem 73(7):1163-1172.

Volesky, B. (1990). In: Volesky B. (Ed) Biosorption of heavy metals. CRC press Boca Raton. Florida.

Workentine, M. L.; Harrison, J. J.; Stenroos, P. U.; Ceri, H. and Turner, R. J. (2008). Pseudomonas fluorescens view of the periodic table. Environ. Microbiol. 10:238-250. 


\section{ARABIC SUMMARY}

التراكم الحيوي للمعادن الثقيلة بواسطة بكتريا الفيبريو الجينوليتكس(Vibririo alginolyticus)(المعزولة منئ من مخلقات مصنع الحديد والصلب بحلوان الفئريان

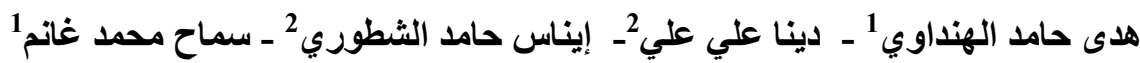

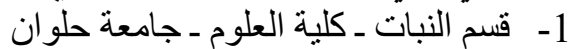

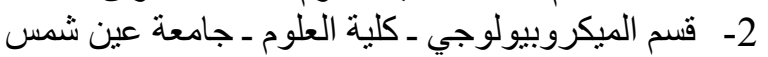

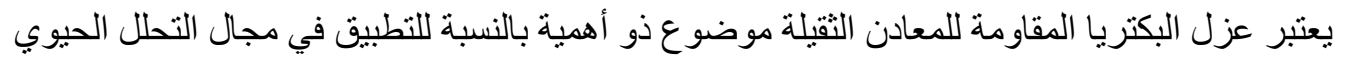

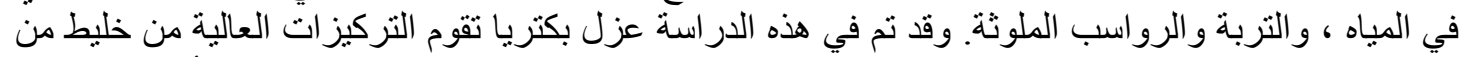

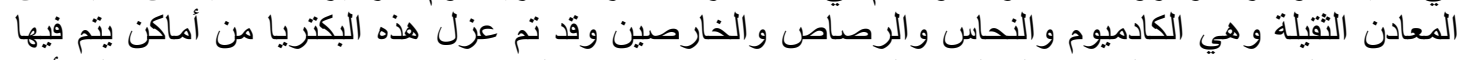

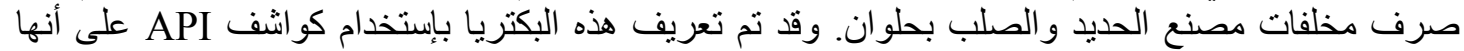

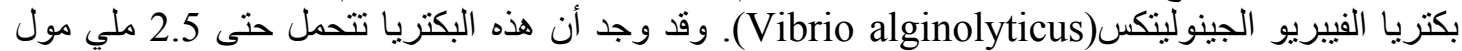

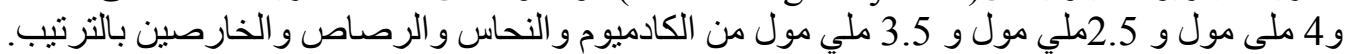

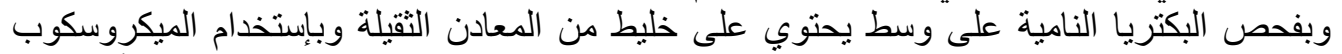

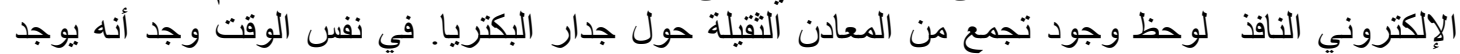

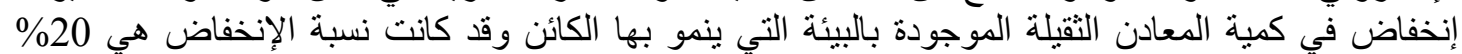

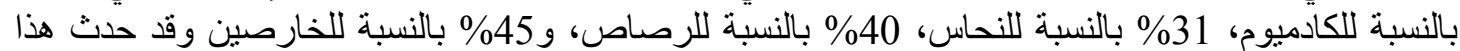

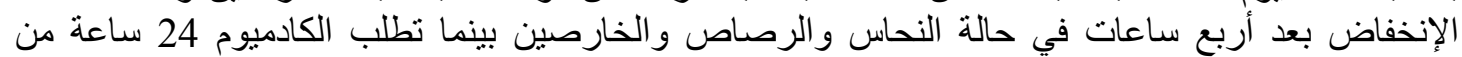
التحضين حتى يتم خفض نسبته و عليه فقد يستخدم هذا الكائن في التعجيل بالتحلل الحيوي الميكروبي في المواقع التي تتعرض للتلوث 